\title{
Cocaine Uptake Is Decreased in the Brain of Detoxified Cocaine Abusers
}

\author{
N. D. Volkow, M.D., G.-J. Wang, M.D., J. S. Fowler, Ph.D., J. Logan, Ph.D., R. Hitzemann, Ph.D., \\ S. J. Gatley, Ph.D., R. R. MacGregor, Ph.D., and A. P. Wolf, Ph.D.
}

Binding of $\left[{ }^{11} C\right]$ cocaine in brain was measured with positron emission tomography in 12 detoxified cocaine abusers and in 20 controls to evaluate if there were changes in cocaine binding and in dopamine (DA) transporter availability associated with chronic cocaine use. Nine controls and 10 cocaine abusers had an additional scan with [18F]N-methylspiroperidol to measure dopamine $\mathrm{D}_{2}$ receptors. Cocaine abusers had significantly lower uptake of $\left[{ }^{11} \mathrm{C}\right]$ cocaine in brain $(6.2 \pm 1 \%$ dose/cc tissues) than controls $(7.7 \pm 2 \%)$. The distribution volumes $(D V)$ for $\left.{ }^{[11} \mathrm{C}\right]$ cocaine were reduced in basal ganglia $(B G)$, cortex, thalamus, and cerebellum $(C B)$ of cocaine abusers. However there were no differences in the ratio of the $D V$ in $B G$ to that in $C B$, which is an estimate of $D A$ transporter availability. Values for $D A D_{2}$ receptor availability were decreased in cocaine abusers and did not correlate with estimates of dopamine transporter availability. In summary, detoxified cocaine abusers showed decreased uptake of cocaine in brain but did not show changes in DA transporter availability. [Neuropsychopharmacology 14:159-168, 1996]
KEY WORDS: $\left[{ }^{11} \mathrm{ClCocaine;} \mathrm{Dopamine} \mathrm{transporter;} \mathrm{Drug}\right.$ dependence; $C B F$; Dopamine receptors; $[18 F] N$ methylspiroperidol

Cocaine's ability to inhibit the dopamine (DA) transporter and to increase synaptic DA concentration in nucleus accumbens have been linked to its reinforcing properties (Ritz et al. 1987; Wise 1990; Woolverton and Johnson 1992; De Wit and Wise 1977; Johanson and Fischman 1989; Koob and Bloom 1988). The extent to which chronic cocaine changes DA transporters is much less clear. Numerous studies in animals have been done to investigate changes in DA transporters with chronic cocaine. These studies have yielded inconsistent results. For example studies measuring DA transporter func-

From the Brookhaven National Laboratory (NDV, GJW, JSF, JL, SIG, RRM, APW), Upton, New York; Department of Psychiatry (NDV, RH), State University of New York at Stony Brook, Stony Brook, New York; Veterans Administration Hospital (RH), Northport, New York.

Address correspondence to: Nora D. Volkow, M.D., Medical Department, Brookhaven National Laboratory, Upton, NY 11973.

Received November 18, 1994; revised April 7, 1995; accepted April 26, 1995. tion after chronic cocaine have shown increases (NG et al. 1991; Missale et al. 1985; Yi and Johnson 1990; Parsons et al. 1993) as well as decreases in nucleus accumbens (Izenwasser and Cox 1990) and no changes in striatum (Izenwasser and Cox 1990; Baker et al. 1993). Studies measuring DA transporter concentration have also been inconsistent with some investigators documenting increases immediately after cocaine discontinuation (Wilson et al. 1992), others decreases after cocaine withdrawal (Farfel et al. 1992; Sharpe et al. 1991; Hitri and Wyatt 1993; Pilotte et al. 1994), and others no change (Benmansour et al. 1992; Kula and Baldessarini 1991; Allard et al. 1990; Peris et al. 1990). Inconsistencies are also found in post mortem human brain studies, with reports documenting increases (Little et al. 1993) as well as decreases in DA transporters (Hitri et al. 1994; Hurd et al. 1993). Factors contributing to the inconsistencies appear to relate to differences among brain regions, to the time at which the measurements were made after last drug use, to the methods used as well as to the radioligand used for quantification of DA transporters. In this respect it is also interesting to note that the bioavailability of cocaine may change after chronic cocaine administration (Pan et al. 1991), and this may 
affect in vivo measurements that use cocaine or cocainerelated ligands.

Positron emission tomography (PET) is an imaging technique that enables the measurement of drug pharmacokinetics, regional brain function, as well as neurotransmitter activity in the living brain. It has been used to assess the behavior of cocaine in the human brain (Fowler et al. 1989) as well as its regional brain metabolic effects after acute (London et al. 1990) and chronic administration (Volkow et al. 1991; Volkow et al. 1992). PET studies measuring neurochemical changes in the chronic cocaine abusers have demonstrated significant decreases in $\mathrm{DA} \mathrm{D}_{2}$ receptors during early (Volkow et al. 1990) and late detoxification (Volkow et al. 1993) as well as decreased brain DA metabolism (Baxter et al. 1988). To our knowledge, no PET studies have been reported on DA transporters in cocaine abusers.

We have previously shown that $\left[{ }^{11} \mathrm{Cl}\right.$ cocaine binds predominantly to the DA transporter (Fowler et al. 1989) and that it is sensitive to changes in DA transporter density occurring with aging (Volkow et al. 1994). In the present study we used PET and $\left[{ }^{11} \mathrm{C}\right]$ cocaine to evaluate DA transporter availability as well as cocaine uptake in the brain of detoxified cocaine abusers. For this purpose we evaluated 12 cocaine abusers between 3 to 6 weeks of detoxification. Four of these cocaine abusers were rescanned after they completed a 3-month inpatient rehabilitation period. Twenty normal subjects were used as control, and eight of them underwent a second scan 3 to 12 weeks later to assess the reproducibility of repeated measurements. We also evaluated the relationship between DA transporter and $\mathrm{DA}_{2}$ receptor availability in those subjects for whom we had also obtained scans with $\left[{ }^{18} \mathrm{~F}\right] \mathrm{N}$-methylspiroperidol (NMS) (Volkow et al. 1993).

\section{METHODS}

\section{Subjects}

Cocaine abusers: 12 male right-handed subjects (age $36 \pm 8$ years) who met DSM-III-R criteria for cocaine dependence were recruited from the detoxification unit of the Northport Veterans Administration Medical Center (VA). Inclusion criteria were: (1) DSM-III-R diagnostic criteria for active cocaine dependence, (2) continuous use of cocaine for at least the prior 6 months with claimed cocaine use of at least "four grams" a week (estimated cost $\$ 400 /$ week), (3) the use of cocaine as free-base or as crack, (4) expressed willingness to participate in a 3-month inpatient rehabilitation program, and (5) righthandedness. Exclusion criteria were: (1) current or past psychiatric disease other than cocaine dependence, (2) neurologic signs and/or history of neurologic disease, (3) history of head trauma, (4) history of cardiovascular or endocrinologic disease, (5) current medical illness,
(6) dependence on any substance other than cocaine, nicotine, or caffeine, (7) history of intravenous drug use and/or (8) more than moderate (12 ounces/week) use of ethanol. The clinical characteristics of the patients have been published (Volkow et al. 1993).

Normal controls: 20 male right-handed subjects (age $36 \pm 12$ years) were recruited as controls. Controls were screened for a lack of history of current or past psychiatric or neurologic disease, as well as for lack of history of drug or alcohol abuse (excluding nicotine/caffeine). Exclusion criteria were otherwise as for cocaine abusers.

None of the subjects were taking medication at the time of the study, and any previous medication had been discontinued 8 days before the first PET scan in this study. All subjects for the present study underwent a complete medical, neurologic, and psychiatric evaluation. After recruitment and evaluation, patients were transferred to an inpatient rehabilitation unit where they were to remain for 3 months. Screens for drug use were performed on random urine samples at least twice a week during hospitalization for patients and prior to each PET scan for controls. Informed consent was obtained for all of the subjects after the nature and possible consequences of the studies had been explained.

\section{PET Scans}

The PET scans were done on a CT1-931 tomograph (15 slices, spatial resolution: $6.5 \times 6.0 \times 6.0 \mathrm{~mm}$ Full Width Half Maximum). Procedures for the PET scans involved the following: individualized molded head holders were used to assure $\pm 2 \mathrm{~mm}$ positioning and repositioning in the PET camera using a vertical and horizontal laser alignment system and the canthomeatal and the medial sagittal lines as references. Before the PET studies, two catheters were inserted, one in the antecubital vein for radiotracer injection and the other in the radial artery for blood sampling. $\left[{ }^{11} \mathrm{C}\right]$ Cocaine was synthesized as described previously (Fowler et al. 1989). Prior to $\left[{ }^{11} \mathrm{C}\right]$ cocaine injection, a transmission scan of the head was taken to correct for attenuation of the $511 \mathrm{keV}$ annihilation photons. Emission scans were started immediately after injection of 5 to $10 \mathrm{mCi}$ (specific activity $>100$ $\mathrm{mCi} / \mu \mathrm{mol}$ at time of injection) and sequential scans were obtained for a total of 45 minutes. Scans were carried out under resting conditions (supine, eyes open, ears unplugged), noise was kept to a minimum, and the room was dimly illuminated.

Arterial blood samples were obtained throughout the procedure to measure total radioactivity and fraction of radioactivity as unchanged $\left[{ }^{11} \mathrm{C}\right]$ cocaine. Unchanged $\left[{ }^{11} \mathrm{C}\right]$ cocaine in plasma was measured in $(0.5 \mathrm{ml})$ samples taken at 1,5,10, and 30 minutes. For this purpose $1 \mathrm{cc}$ of acetonitrile was added to the samples, and the mixture was sonicated and centrifuged. The superna- 
tant was analyzed by HPLC (Phenomenex, Spherisorb silica column $4.6 \times 250 \mathrm{~mm}$, eluted with $5 \mathrm{mmol} / \mathrm{L}$ $\mathrm{NH}_{4} \mathrm{ClO}_{4}$ in methanol (pH 7.0) at flow $1.0 \mathrm{ml} / \mathrm{min}$ ) with ultraviolet detection and radioactivity assay of fractions. A sample of unlabeled cocaine was added to the supernatant, and the fraction of labeled cocaine in each sample was taken as the amount of radioactivity coeluting with the unlabeled cocaine relative to the total amount injected into the HPLC.

Nine of the normal controls and 10 of the cocaine abusers had an additional scan with $\left[{ }^{18} \mathrm{~F}\right] \mathrm{N}$-methylspiroperidol (NMS) done within 10 days of the $\left[{ }^{11} \mathrm{C}\right]$ cocaine scan. NMS scans from these subjects were part of a larger study evaluating DA $D_{2}$ receptor availability in cocaine abusers for which the results as well as the methodology have been published (Volkow et al. 1993). Briefly, emission scans were started immediately after injection of 4 to $6 \mathrm{mCi}$ (specific activity 0.5 to $1.0 \mathrm{Ci} / \mu \mathrm{mol}$ at time of injection) of NMS and sequential scans were obtained for a total of 180 minutes. Arterial blood samples were obtained throughout the scanning to measure blood gases as well as total activity and unchanged NMS.

\section{Image Analysis}

Regions of interest (ROI) were chosen directly in the emission scans using Matsui and Hirano's neuroanatomic atlas as reference (1979). Regions of interest were obtained for basal ganglia (BG), cerebellum (CB), thalamus $(\mathrm{TH})$, and occipital cortex (OC) using a template that has previously been described (Volkow et al. 1992). In addition a measure of "global" uptake was obtained by averaging the activity in the five central slices. An estimate of total brain "peak" uptake was obtained by multiplying the average concentration obtained from the global measures at peak uptake (expressed as \% dose per cc tissue) by 1,500 (average weight of the human brain) (Blinkov and Glezer 1968).

The time activity curves for tissue concentration and for unchanged tracer in plasma were used to calculate the distribution volumes (DV) as well as the rate of transfer of $\left[{ }^{11} \mathrm{C}\right]$ cocaine from plasma to brain (K1) for the BG, TH, OC, and CB using "Logan plots" (Logan et al. 1990). The Logan plot corresponds to the slope of

$$
\int_{0}^{t} R O I\left(t^{\prime}\right) d t^{\prime} / R O I(t) \text { vs. } \int_{0}^{t} C p\left(t^{\prime}\right) d t^{\prime} / R O I(t)
$$

where ROI and $\mathrm{Cp}$ are functions of time describing the variation of tissue radioactivity and plasma radioactivity respectively. For a three-compartmental model (such as would be applicable to binding of cocaine to DA transporters in basal ganglia) the DV is given by

$$
\mathrm{DV}_{\mathrm{BG}}=\mathrm{K}_{1} / \mathrm{k}^{\prime}{ }_{2}(1+\mathrm{NS}+(\mathrm{Bmax}-\mathrm{L}) / \mathrm{Kd})
$$

where Bmax is the total DA transporter concentration, $\mathrm{L}$ is the concentration of endogenous neurotransmitter bound to the transporter, $\mathrm{Kd}$ is the ligand transporter equilibrium dissociation constant, and NS represents the ratio of kinetic constants for nonspecific binding, which is assumed to be sufficiently rapid that it is always in a steady state. $K_{1}$ and $k_{2}$ are plasma-to-tissue and tissue-to-plasma transport constants, which are functions of blood flow, capillary permeability, and plasma protein binding. According to steady-state model (the tissue concentration is assumed to remain constant over the time of capillary transit).

$$
\mathrm{K}_{1}=\mathrm{F}\left(1-\mathrm{e}^{-\mathrm{PS}_{1} / \mathrm{F}}\right)
$$

and

$$
\mathrm{k}_{2}=\left(\mathrm{PS}_{2} / \mathrm{PS}_{1}\right) \mathrm{F}\left(1-\mathrm{e}^{-\mathrm{PS}_{1} / \mathrm{F}}\right)
$$

(where $\mathrm{F}$ refers blood flow) so that

$$
\mathrm{K}_{1} / \mathrm{k}_{2}=\mathrm{PS}_{1} / \mathrm{PS}_{2}=\mathrm{PS}^{\prime}{ }_{1}{ }_{p} /\left(\mathrm{PS}^{\prime}{ }_{2} \mathrm{f}_{\mathrm{NS}}\right)
$$

$\mathrm{PS}_{1}{ }_{1}$ and $\mathrm{PS}_{2}{ }_{2}$ are the plasma to tissue and tissue to plasma permeabilities. The effective permeability $\mathrm{PS}_{1}=$ $\mathrm{PS}^{\prime} f_{\mathrm{p}}$ is directly proportional to the free fraction in plasma $f_{\mathrm{p}}$, and $\mathrm{PS}_{2}=\mathrm{PS}_{2} f_{\mathrm{NS}}$ is a function of the free fraction (of nonspecifically bound) in tissue $f_{\mathrm{NS}}$. The DV for a nonreceptor region such as the cerebellum (CB) is given by

$$
\mathrm{DV}_{\mathrm{CB}}=\mathrm{K}_{1} / \mathrm{k}_{2}(1+\mathrm{NS})
$$

Because the DV is proportional to $\mathrm{PS}_{1} / \mathrm{PS}_{2}$, it is a function of plasma protein binding and tissue nonspecific binding. We therefore used the ratio of the $\mathrm{DV}$ in the ROI to that in CB as model parameter to estimate DA transporter availability. This ratio is independent of blood flow, plasma protein binding, and permeability and is a linear function of DA transporter concentration.

$$
\mathrm{DV}_{\mathrm{BG}} / \mathrm{DV}_{\mathrm{CB}}=1+\left[\frac{B \max -L}{K d}\right]\left[\frac{1}{1+N S}\right]=1+\left[\frac{B \max ^{\prime}}{K d^{\prime}}\right]
$$

where we have defined $(B \max -\mathrm{L})=\mathrm{Bmax}^{\prime}$, and $\mathrm{Kd}=$ $K d^{\prime} f_{N S}\left(\right.$ where $f_{N S}=1 /(1+N S)$ ).

Dopamine $\mathrm{D}_{2}$ receptor availability was obtained using the "ratio index" (Smith et al. 1988), which corresponds to the slope of the ratio of the radioactivity in striatum to radioactivity in cerebellum plotted against time (duration of scan $=180$ minutes). Details on the methodology have been published (Volkow et al. 1993).

Regional differences between the normal controls and the chronic cocaine abusers were tested with twotailed, unpaired student's $t$-test. For those subjects undergoing repeated scans, differences between the first and the second scan were compared with paired $t$-tests. Comparisons of repeated scans were done separately for the normals and for the cocaine abusers.

The relation between DA transporter availability $\left(D V_{B G} / D V_{C B}\right)$ and that of $D A D_{2}$ receptors (ratio index for NMS) was measured using Pearson product moment correlation analysis. 


\section{RESULTS}

The brain uptake of $\left[{ }^{11} \mathrm{C}\right]$ cocaine was significantly lower in cocaine abusers than in controls. In normal controls approximately $7.8 \pm 2 \%$ of the injected dose per cc of tissue went into the brain, whereas in the cocaine abusers only $6.1 \pm 1 \%$ (Table 1 ). After 3 months of detoxification, the uptake remained significantly lower than that of the normal controls. Similarly, $\mathrm{K}_{1}$ values were significantly lower in cocaine abusers than in controls. $K_{1}$ for BG corresponded to $0.53 \pm 0.10$ in the normal controls and $0.49 \pm 0.08$ in the cocaine abusers. Though not significant $\mathrm{K}_{1}$ 's were also reduced in thalamus and cerebellum (Table 1). The lower uptake of $\left[{ }^{11} \mathrm{C}\right]$ cocaine in $B G$ is apparent in Figure 1, which shows the averaged time activity curve for $\left[{ }^{11} \mathrm{C}\right]$ cocaine in $\mathrm{BG}$ for the cocaine abusers and for the normal controls.

Evaluation of the DV values revealed linear plots from early time points for both normal and cocaine abuser (Figure 2). The DV were significantly lower for all brain regions in cocaine abusers tested during early detoxification than in controls (Figure 3). With 3 months of detoxification there was an associated increase in the DV in BG, but there were no changes in the DV in thalamus or in cerebellum. In the controls none of the measures changed with the test-retest evaluation (Table 2).

In contrast, assessment of the DV ratios (DV $\mathrm{ROI} /$ $\mathrm{DV}_{\mathrm{CB}}$ ) revealed no differences between normals and cocaine abusers tested during early and late detoxification (Table 1). There were also no changes in DV ratios upon repeated examination for the normals or for the cocaine abusers (Table 2).

Table 1. Regional Uptake and Binding of $\left[{ }^{11} \mathrm{C}\right]$ Cocaine in the Brain of Controls and of Cocaine Abusers

\begin{tabular}{lccc}
\hline & $\begin{array}{c}\text { Normal } \\
(\boldsymbol{n}=\mathbf{2 0})\end{array}$ & $\begin{array}{c}\text { Cocaine Abusers } \\
(\boldsymbol{n}=\mathbf{1 2})\end{array}$ & \\
\hline $\begin{array}{l}\text { Brain uptake } \\
\text { (\% dose) }\end{array}$ & & & \\
$\mathrm{K}_{1 \mathrm{BG}}$ & $0.72 \pm 2.10$ & $6.19 \pm 1.40$ & $p<.05$ \\
$\mathrm{~K}_{1 \mathrm{TH}}$ & $0.53 \pm 0.10$ & $0.36 \pm 0.06$ & $p<.01$ \\
$\mathrm{~K}_{1 \mathrm{CB}}$ & $0.42 \pm 0.11$ & $0.43 \pm 0.10$ & $p<.06$ \\
$\mathrm{DV}_{\mathrm{BG}} / \mathrm{DV}_{\mathrm{CB}}$ & $1.71 \pm 0.11$ & $1.72 \pm 0.06$ & $p<.06$ \\
$\mathrm{DV}_{\mathrm{TH}} / \mathrm{DV}_{\mathrm{CB}}$ & $1.22 \pm 0.14$ & $1.31 \pm 0.22$ & $\mathrm{NS}$ \\
$\mathrm{DV}_{\mathrm{OC}} / \mathrm{DV}_{\mathrm{CB}}$ & $1.03 \pm 0.19$ & $1.07 \pm 0.17$ & $\mathrm{NS}$ \\
\hline
\end{tabular}

Values correspond to the scans obtained during early detoxification in the cocaine abusers and to the scans obtained in the first evaluation in controls.

Averaged values for normal controls and for cocaine abusers for uptake of $\left[{ }^{11} \mathrm{C}\right]$ cocaine in brain, for the $\mathrm{K}_{1}$ (transfer constant of $\left[{ }^{11} \mathrm{C}\right]$ cocaine from plasma to tissue) of $\left[{ }^{11} \mathrm{C}\right]$ cocaine in basal ganglia (BG), in thalamus $(\mathrm{TH})$, and in cerebellum (CB), and for the ratios of the distribution volume (DV) in $B G$ to $C B\left(D V_{B G} / D V_{C B}\right), D V$ in TH to $C B\left(D V_{B G} / D V_{C B}\right)$ and $D V$ in occipital cortex $(\mathrm{OC})$ to $\mathrm{CB}\left(\mathrm{DV}_{\mathrm{OC}} / \mathrm{DV}_{\mathrm{CB}}\right)$. Brain uptake of $\left[{ }^{11} \mathrm{C}\right] \mathrm{co}-$ caine as well as the regional values for $\mathrm{K}_{1}$ were significantly lower in cocaine abusers than in controls. The DV ratios did not differ between the groups.

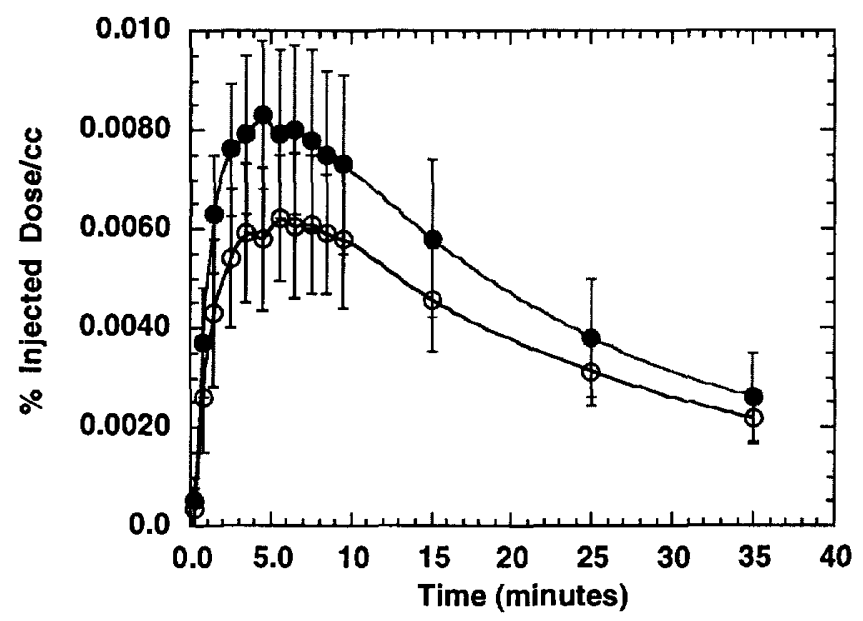

Figure 1. Time activity curves for $\left[{ }^{11} \mathrm{C}\right]$ cocaine in basal ganglia (BG) in normal controls (filled circles) and in cocaine abusers (open circles). Values correspond to average measures and SD for the 20 controls and the 12 cocaine abusers. The concentration of $\left[{ }^{11} \mathrm{C}\right]$ cocaine in $\mathrm{BG}$ was significantly lower in cocaine abusers than in controls for all time points except those obtained within 1 minute of $\left[{ }^{11} \mathrm{C}\right]$ cocaine injection and those obtained 25 minutes after its injection.

An analysis of the plasma concentration of unchanged cocaine revealed no differences in the integrated plasma concentration of unchanged tracer between normals and cocaine abusers during early or late detoxification (Table 3).

As in our previous study, this subgroup of cocaine abusers had significantly lower values for the "ratio index" than controls; normals $=3.10 \pm 0.49$, cocaine abusers $=2.51 \pm 0.5 ; p<.05$. The correlation analysis between the $\mathrm{DV}_{\mathrm{BG}} / \mathrm{DV}_{\mathrm{CB}}$ for $\left[{ }^{11} \mathrm{C}\right]$ cocaine and the "ratio index" for $\left[{ }^{18} \mathrm{~F}\right] N M S$ was not significant $(r=0.15)$ (Figure 4).

\section{DISCUSSION}

This study documents decreases in brain uptake of $\left[{ }^{11} \mathrm{C}\right]-$ cocaine in chronic cocaine abusers relative to normal subjects. The decreases in brain uptake of $\left[{ }^{11} \mathrm{C}\right]$ cocaine persisted in the four patients who completed a 3-month inpatient detoxification program suggesting that they do not represent a temporary adaptation process but rather a long-lasting effect. The decreased brain uptake was not due to differences in rate of $\left[{ }^{11} \mathrm{C}\right]$ cocaine metabolism, because the total plasma concentration of unchanged $\left[{ }^{11} \mathrm{C}\right]$ cocaine was comparable for both groups of subjects. Furthermore, because both groups of subjects did not differ in their weight (normals $=189 \pm 39 \mathrm{lb}$, cocaine abusers $=195 \pm 34 \mathrm{lb}$ ), it is also unlikely that differences represent differences in distribution of cocaine in body compartments such as fat tissue. Because cocaine is 

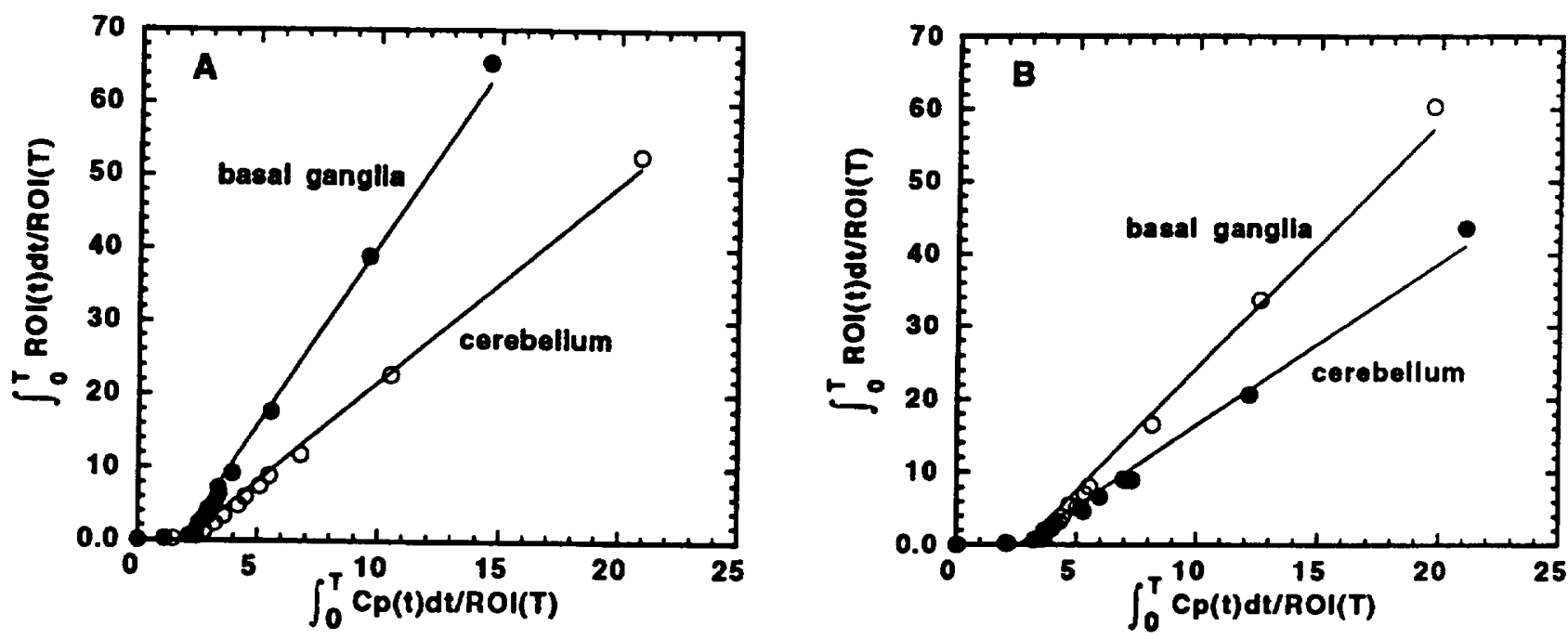

Figure 2. Graphical analysis for the distribution volumes in basal ganglia and cerebellum in a normal control(A) and in a cocaine abuser (B) ROI(T) refers to radioactivity in the region of interest at time $\mathrm{T}$. $\mathrm{Cp}(\mathrm{t})$ is the plasma radioactivity corrected for metabolites. Notice the smaller slopes in the cocaine abuser than in the control.

highly permeable (Mule et al. 1976) under conditions of decreased cerebral blood flow (CBF), its delivery could become rate limiting. Hence decreased brain uptake of cocaine in cocaine abusers could reflect the marked reductions in CBF associated with chronic cocaine abuse (Volkow et al. 1988).

The reduced cocaine uptake in the brain of cocaine abusers differs from the animal studies that have shown increases in brain concentration of cocaine (Pan et al.

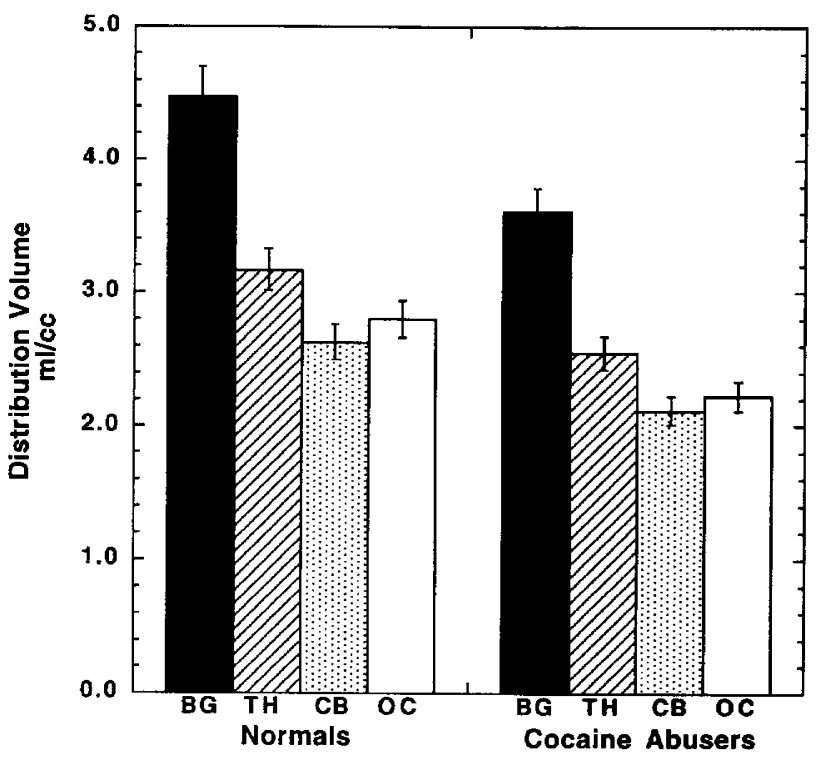

Figure 3. Values for the DV for $\left[{ }^{11} \mathrm{C}\right]$ cocaine in basal ganglia (BG), thalamus (TH), occiptal cortex (OC) and cerebellum (CB) in normals and cocaine abusers. The DV measures were significantly lower in cocaine abusers than in controls $(p<.05)$.
1991; Izenwasser and Cox 1992) as well as differences in brain pharmacokinetics of cocaine (Nayak et al. 1976) after chronic cocaine administration. These discrepancies could relate to species differences, routes of administration as well as differences associated with the chronic administration of cocaine in an experimental setting versus those observed in the real life situation. For example, increased brain concentration after chronic cocaine was observed when cocaine was administered intraperitoneally but not when it was administered intravenously, and the increases were found to be related to changes in cocaine absorption in the intraperitoneal cavity (Pan et al. 1991). Also, increases in brain cocaine after chronic cocaine concentration were reported when cocaine was administered intermittently but not when it was administered via minipumps (Reith et al. 1987; Izenwasser and Cox 1992).

This study also documents a decrease in binding potential of cocaine in the brain of cocaine abusers as assessed by the DV. Though reductions in CBF could limit the uptake of $\left[{ }^{11} \mathrm{C}\right]$ cocaine in brain, the DV measurements that represent a steady-state quantity (although it is not necessary to measure it under steady-state conditions) should not be affected by CBF. The DV has been shown to be insensitive to physiologic changes in blood flow (Holthoff et al. 1991; Logan et al. 1994). It is more likely that the reduced DV in cocaine abusers could reflect decreased uptake due to an increase in plasma protein binding or a general decrease in permeability of bloodbrain barrier to the uptake (but not the loss) of cocaine. In principle the reduced DV values for $\mathrm{C}-11$ cocaine in cocaine abusers could reflect a decrease in the plasmafree fraction for $\mathrm{C}-11$ cocaine. If the free fraction differs between the cocaine abuser and control groups, then our 
Table 2. Test-Retest Reproducibility for $\left[{ }^{11} \mathrm{C}\right]$ cocaine in Controls and Effects of Detoxification in Cocaine Abusers

\begin{tabular}{lccccc}
\hline & \multicolumn{2}{c}{ Normal } & & \multicolumn{2}{c}{ Cocaine Abusers } \\
\cline { 2 - 3 } & $\begin{array}{c}\text { First Scan } \\
(\boldsymbol{n}=\mathbf{8})\end{array}$ & $\begin{array}{c}\text { Second Scan } \\
(\boldsymbol{n}=\mathbf{8})\end{array}$ & & $\begin{array}{c}\text { Early Detox } \\
(\boldsymbol{n}=\mathbf{4})\end{array}$ & $\begin{array}{c}\text { Late Detox } \\
(\boldsymbol{n}=\mathbf{4})\end{array}$ \\
\hline $\begin{array}{l}\text { Brain uptake } \\
(\% \text { dose })\end{array}$ & $7.00 \pm 1.23$ & $7.20 \pm 1.84$ & & $6.50 \pm 1.16$ & $5.78 \pm 0.35$ \\
$\mathrm{DV}$ & $4.40 \pm 1.06$ & $4.41 \pm 0.85$ & & $3.43 \pm 0.39$ & $3.88 \pm 0.53^{a}$ \\
$\mathrm{DV}$ & $3.33 \pm 0.78$ & $3.10 \pm 0.61$ & & $2.81 \pm 0.17$ & $3.06 \pm 0.25$ \\
$\mathrm{DV}$ & $2.52 \pm 0.52$ & $2.56 \pm 0.45$ & & $2.07 \pm 0.28$ & $2.35 \pm 0.39$ \\
$\mathrm{DV}$ & $1.74 \pm 0.14$ & $1.72 \pm 0.70$ & & $1.66 \pm 0.08$ & $1.66 \pm 0.07$ \\
$\mathrm{DV}$ & $1.32 \pm 0.22$ & $1.23 \pm 0.05$ & & $1.30 \pm 0.14$ & $1.22 \pm 0.14$ \\
\hline
\end{tabular}

Averaged values for repeated studies done with $\left[{ }^{11} \mathrm{C}\right]$ cocaine in normal controls to assess test-retest reproducibility and in cocaine abusers to assess the effects of 3 months of detoxification. Abbreviations are as for Table 1. Comparisons between repeated measurements used paired $t$ tests (two-tail).

$a_{p}<.05$.

None of the parameters changed in the repeated measurements in the controls. In the cocaine abusers the only significant change with detoxification was an increase in the DV in BG.

use of the total plasma concentration as the input function for DV calculations may not be appropriate. The alternative explanation that cocaine abusers exhibit a general decrease in the permeability of the blood-brain barrier to the uptake, but not the loss, of cocaine is unlikely, as cocaine is presumed to enter the brain by passive diffusion related to its lipophilicity.

In contrast to changes in the DV values for the individual regions, the $D V$ ratios including the $D V_{B G} / D V_{C B}$ did not differ between the two groups of subjects. The

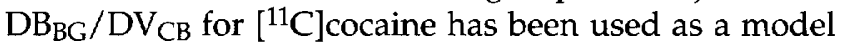
parameter to estimate DA transporter availability-a measure pertaining to DA transporters that are available to interact with the tracer and not necessarily total DA transporter concentration. The $\mathrm{DV}_{\mathrm{BG}} / \mathrm{DV}_{\mathrm{CB}}$ for $\left[{ }^{11} \mathrm{C}\right]$ cocaine is reduced by relatively low doses of cocaine as well as by drugs that inhibit the DA transporter (Volkow et al. 1995) and has been found to be sensitive to decreases in DA transporters with aging (Volkow et al. 1994). It mainly reflects cocaine binding to the high affinity DA transporter (Volkow et al. 1995). The fact that we were unable to document changes in cocaine abusers would indicate that there are no changes in high affinity DA transporter availability in cocaine abusers after protracted withdrawal. These results are in agreement with animals studies (Benmansour et al. 1992; Kula and Baldessarini 1991; Allard et al. 1990; Peris et al. 1990), which have indicated no evidence of changes in DA transporters with chronic change. Though studies have also shown that chronic cocaine decreases DA transporters (Farfel et al. 1992; Sharpe et al. 1991; Hitri and Wyatt 1993; Hitri et al. 1994; Hurd and Herkenham 1993) as well as DA transporter mRNA (Cerruti et al. 1993) those changes have been documented predominantly in the nucleus accumbens and in the prefrontal cortex and not in striatum (except for Hurd and Herkenham 1993). The PET measurements predominantly reflect dorsal striatum and not ventral striatum where the nucleus accumbens is located. It is also possible that we failed to document changes in DA transporter availability in cocaine abusers due to the fact that these changes tend to recover relatively rapidly after detoxification. A

Table 3. Concentration of Unchanged $\left[{ }^{11} \mathrm{C}\right]$ Cocaine in Plasma and Percent Metabolized $\left[{ }^{11} \mathrm{C}\right]$ Cocaine in Controls and Cocaine Abusers

\begin{tabular}{|c|c|c|c|c|}
\hline & \multicolumn{2}{|c|}{ Normal } & \multicolumn{2}{|c|}{ Cocaine Abusers } \\
\hline & $10 \mathrm{~min}$ & $30 \mathrm{~min}$ & $10 \mathrm{~min}$ & $30 \mathrm{~min}$ \\
\hline $\begin{array}{l}\text { Integral of }\left[{ }^{11} \mathrm{C}\right] \text { cocaine } \\
\text { in plasma }\end{array}$ & $3,071 \pm 400$ & $4,505 \pm 770$ & $2,727 \pm 628$ & $4,015 \pm 1,162$ \\
\hline Percent metabolized & $9.8 \pm 8.0$ & $19.6 \pm 3.0$ & $10.6 \pm 4.0$ & $28.7 \pm 12.0$ \\
\hline
\end{tabular}

Values for the integrated concentration of unchanged [ ${ }^{11} \mathrm{C}$ ]cocaine in plasma and for percentage of metabolized $\left.{ }^{11} \mathrm{C}\right]$ cocaine at 10 and at 30 minutes after injection of $\left.{ }^{11} \mathrm{C}\right]$ cocaine, for the normal controls and for the cocaine abusers. Both groups had comparable concentrations of unchanged $\left[{ }^{11} \mathrm{C}\right]$ cocaine in plasma. 


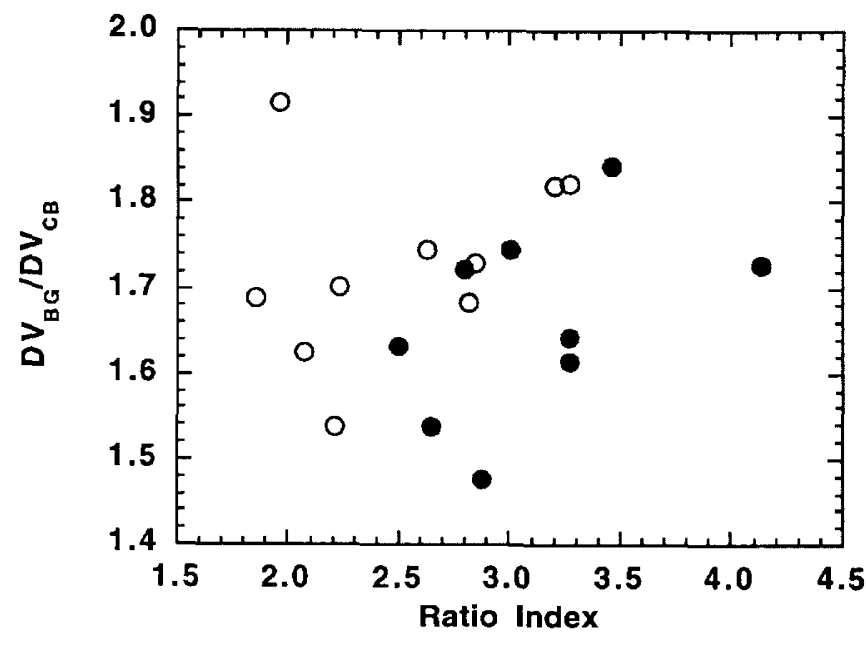

Figure 4. Correlation between the ratio of the DV in $B G$ to that in $\mathrm{CB}\left(\mathrm{DV}_{\mathrm{BG}} / \mathrm{DV}_{\mathrm{CB}}\right)$ obtained with $\left.{ }^{11} \mathrm{C}\right]$ cocaine as an estimate of DA transporter availability and the "ratio index" obtained with $\left[{ }^{18} \mathrm{~F}\right] \mathrm{N}$-methylspiroperidol as an estimate of $\mathrm{DA}_{2}$ receptor availability. Normal controls are indicated with closed circles and cocaine abusers with open circles. The correlation between these two parameters was not significant.

preliminary study that evaluated DA transporter availability in cocaine abusers with SPECT and $\left.{ }^{123}{ }^{12}\right] \beta-C I T$ documented increases immediately after detoxification which recover 2 to 4 weeks after detoxification (Malison et al. 1994). Similarly, an autoradiographic study showed decreases in DA transporters in the brain of chronically treated rats immediately after cocaine withdrawal and increases 4 days after cocaine discontinuation (Graham et al. 1994). It has also been noted (Hitri et al. 1994) that most studies that documented decreases in DA transporters with chronic cocaine used cocaine analogue ligands, whereas those that did not document changes used noncocaine-related ligands. It is therefore possible that changes in the conformation of the DA transporter with chronic cocaine could affect the binding of some ligands but not of others. In fact, one study has documented decreased striatal binding of a cocaine analogue (WIN 35428) but not of a noncocaine-related DA transporter ligand (GBR 12935) after withdrawal (3 weeks) from chronic cocaine (Wilson et al. 1992).

In interpreting the failure to observe changes in DA transporter availability in cocaine abusers some of the limitations of the experimental strategies should be addressed. One is the relatively low specific to nonspecific binding ratio of $\left[{ }^{11} \mathrm{C}\right]$ cocaine, which limits its sensitivity as a tracer to measure DA transporter availability. Another confounding factor was the finding of reduced DV in CB of cocaine abusers, which may have led to an overestimation of DA transporter availability as assessed by the $\mathrm{DV}_{\mathrm{BG}} / \mathrm{DV} \mathrm{CB}_{\mathrm{C}}$.

The value for $D A D_{2}$ receptor availability was not associated with the value for DA transporter availability measured within the same subject. In the cocaine abusers, the lack of a significant association is also evidenced by the significant decreases in $D A D_{2}$ receptor but not in DA transporter availability. Dopamine $\mathrm{D}_{2}$ receptors, as measured with PET, predominantly label postsynaptic receptors, which are mostly located in GABAergic and acetylcholine neurons (Drukarch et al. 1990; Stoof and Kebabian 1982), whereas DA transporters are located in the terminals of DA neurons. Thus, our results suggest that the decreases in $\mathrm{DA}_{2}$ receptors in cocaine abusers indicate changes in GABA and perhaps acetylcholine neurons rather than DA neurons. Therefore the abnormal responses observed in cocaine abusers after DA agonists (Hollander et al. 1990; Hitzemann et al. in press) and antagonists (Choy Kwang and Lipton 1989; Kumor et al. 1987; Hegarty et al. 1990) could reflect dysfunction of GABAergic and or cholinergic cells and not just dysfunction of DA cells. Obviously more work is required to determine the extent to which GABAergic and acetylcholine neurons are involved in the changes observed in chronic cocaine abusers.

The relatively high uptake of $\left[{ }^{11} \mathrm{C}\right]$ cocaine in thalamus is intriguing for although studies have reported the presence of $\mathrm{DA} \mathrm{D}_{2}$ receptors in thalamus (Kessler et al. 1993), none to our knowledge has reported the presence of $\mathrm{DA}$ transporters. If one considers $\mathrm{DV} \mathrm{BG}_{\mathrm{BG}} / \mathrm{DV}_{\mathrm{CB}}$ as $B_{\max } / K_{d}+1$, then specific binding $\left(B_{\max } / K_{d}\right)$ corresponds to 0.71 for $B G$ and $0.2-0.3$ for thalamus, that is thalamic-specific binding is $30 \%$ to $42 \%$ that of basal ganglia. These results are similar to those reported in autoradiographic studies in nonhuman primate brain with $\left[{ }^{3} \mathrm{H}\right]$ cocaine for which thalamic/cerebellum ratios were $36 \%$ to $45 \%$ of those for striatum/cerebellum (Madras and Kaufman 1994). Relatively high thalamic binding was also reported for $\left[{ }^{11} \mathrm{C}\right]$ nomifensine another ligand for the DA transporter (Salmon et al. 1990). For the active S-enantiomer of $\left[{ }^{11} \mathrm{C}\right]$ nomifensine the specific binding in thalamus was approximately $31 \%$ that of striatum (Salmon et al. 1990). Although thalamic binding of $\left[{ }^{11} \mathrm{C}\right]$ cocaine and $\left[{ }^{11} \mathrm{C}\right]$ nomifensine may reflect binding to norepinephrine transporters, it is also possible that it reflects binding to DA transporters. In this respect it is interesting to note that specific binding for the DA $\mathrm{D}_{2}$ receptor PET ligands $\left[{ }^{11} \mathrm{C}\right]$ raclopride and $\left[{ }^{18} \mathrm{~F}\right]-\mathrm{N}$-methylspiroperidol in thalamus is $30 \%$ to $40 \%$ that in basal ganglia (Wang et al. 1993). The similar thalamic to striatal rates observed for PET ligands for the DA transporter and those for the DA $D_{2}$ receptors suggests that thalamic binding for $\left[{ }^{11} \mathrm{C}\right]$ cocaine and $\left[{ }^{11} \mathrm{C}\right]$ nomifensine is in part due to binding to DA transporters. However, characterization of $\left[{ }^{11} \mathrm{C}\right]$ cocaine binding in the human brain is required to determine if thalamic binding represents binding to DA transporters and/or binding to serotonin and/or norepinephrine transporters. 
Reduction of brain uptake of cocaine in brain as a consequence of abuse would make cocaine, in principle, less reinforcing for it would be the equivalent of injecting smaller doses. This effect would be accentuated by decreases in $\mathrm{DA} \mathrm{D}_{2}$ receptor availability in cocaine abusers. These mechanisms might explain in part the increasingly higher doses of cocaine used by cocaine abusers with time (Gold 1992). However this study cannot rule out the possibility that differences between cocaine abusers and controls antedated the cocaine use or that tracer doses of cocaine may not parallel the behavior of a pharmacologic dose.

In conclusion, this study documents decreased brain uptake of cocaine as well as decreases in regional DVs for cocaine in the brain of cocaine abusers. However, there was no evidence of changes in DA transporter availability in detoxified cocaine abusers.

\section{ACKNOWLEDGMENTS}

This research was supported in part by the U.S. Department of Energy under Contract DE-ACO2-76CH00016 and NIDA Grant No. 5RO1-DA06891 and NINDS, NS15638. The authors thank David Schlyer, Robert Carciello, and Babe Barrett for Cyclotron operations; Alejandro Levy, Naomi Pappas, and Donald Warner for PET operations; Colleen Shea, Thomas Martin, Darrin Jenkins, and Payton King for radiotracer preparation and analysis; Gail Burr and Kathleen Piscani for subject recruitment; Noelwah Netusil for patient care; and Carol Redvanly for scheduling and organization.

\section{REFERENCES}

Allard P, Ericksson K, Ross SB, Marcusson JO (1990): Unaltered $\left[{ }^{3} \mathrm{H}\right] \mathrm{GBR}-12935$ binding after chronic treatment with dopamine active drugs. Psychopharmacology 102:291294

Baker I, Wyatt RJ, Masserano (1993): Evaluation of dopamine uptake into the substantia nigra, ventral tegmental area and striatum of the rate: Effects of cocaine treatment. Society for Neuroscience 23rd Annual Meeting 19:936

Baxter LR, Schwartz JM, Phelps M, Mazziota JC, Barrio J, Rawson RA, Engel J, Guze BH, Selin C, Sumida R (1988): Localization of neurochemical effects of cocaine and other stimulants in the human brain. J Clin Psychiatry 4:923-926

Benmansour S, Tejani-Butt SM, Hauptmann M, Brunswick DJ (1992): Lack of effect of high-dose cocaine on monoamine uptake sites in rat brain measured by quantitative autoradiography. Psychopharmacology 106:459-462

Blinkov SM, Glezer II (1968): The Human Brain in Figures and Tables: A Quantitative Handbook. New York, Plenum, 166-170

Cerruti C, Pilotte NS, Uhl G, Kuhar MJ (1993): Reduction in dopamine transporter mRNA after cessation of repeated cocaine administration. Mol Brain Res 00:1-7

Choy-Kwang M, Lipton RB (1989): Dystonia related to cocaine withdrawal: A case report and pathogenic hypotheses. Neurology 39:996-997

Dackis CA, Gold MS (1985): New concepts in cocaine addiction: The dopamine depletion hypothesis. Neurosci Biobehav Rev 9:469-477

De Wit H, Wise RA (1977): Blockade of cocaine reinforcement in rats with the dopamine receptor blocker pimozide but not with the noradrenergic blockers phentolamine or phenoxybenzamine. Can J Psychol 31:195-203

Drukarch B, Schepens E, Stoof JC (1990): Muscarinic receptor activation attenuates $D_{2}$ receptor mediated inhibition of acetylcholine release in rat striatum-indications for a common signal pathway. Neuroscience 37:1-9

Farfel GM, Kleven MS, Woolverton WL, Siden LS, Perry BD (1992): Effects of repeated injections of cocaine on catecholamine receptor binding sites, dopamine transporter binding sites, and behavior in rhesus monkey. Brain Res 578:235-243

Fischman MW, Schuster CR, Javaid J. Hatano Y, Davis J (1985): Acute tolerance development to the cardiovascular and subjective effects of cocaine. J Pharmacol Exp Ther 235: $677-682$

Fowler JS, Volkow ND, Wolf AP, Dewey SL, Schlyer D, MacGregor RR, Hitzemann R, Logan J, Bendriem B, Gatley SJ, Christman D (1989): Mapping cocaine binding sites in human and baboon brain sites in vivo. Synapse 4:371-377

Graham JH, Dworkin SI, Porrino LJ (1994): Alterations in dopamine uptake transporter density in cocaine self administering rats appear transient. Society for Neurosciences Abstracts. 24th Annual Meeting 20:1627

Gold MS (1992): Cocaine and (crack): Clinical aspects. In Lowinson JH, Ruiz P, Millman RB, Langrod J (eds), Substance Abuse: A Comprehensive Textbook. Baltimore, Williams \& Wilkins, pp 205-221

Hegarty A, Lipton RB, Merriam (1990): Cocaine as a risk factor for acute dystonic reaction (abst.). Neurology 40 (suppl. 1):146-147

Hitri A, Wyatt RJ (1993): Regional differences in the effect of cocaine on rat brain dopamine transporter binding: Function of time after chronic administration. Clin Neuropharmacol 16:525-539

Hitri A, Casanova MF, Kleinman JE, Wyatt RJ (1994): Fewer dopamine transporter receptors in the prefrontal cortex of cocaine users. Am J Psychiatry 151(7):1074-1076

Hitzemann R, Burr G, Piscani K, Hazan J, Krishnamoorthy G, Cushman P, Baldwin CH, Carrion R, Volkow ND, Hirschowitz J, Handelsman L, Chiaramonte J, Angrist B (1995): Neuroendocrine and clinical features of cocaine withdrawal. Psychiatry Res (in press)

Hollander E, Nunes E, DeCaria C, Quitkin FM, Cooper Th, Wager S, Klein DF (1990): Dopaminergic sensitivity and cocaine abuse: response to apomorphine. Psychiatry Res 33:161-169

Holthoff VA, Koeppe RA, Frei KA, Paradise AH, Kuhl DE (1991): Differentiation of radioligand delivery and binding in the brain validation of a two-compartment model of [ $\left.{ }^{11} \mathrm{C}\right]$ Flumazenil. J Cereb Blood Flow Metab 11:745-75

Hurd YL, Herkenham M (1993): Molecular alterations in the neostriatum of human cocaine addicts. Synapse 13:357369 
Izenwasser S, Cox BM (1990): Daily cocaine treatment produces a persistent reduction of $\left[{ }^{3} \mathrm{H}\right]$ dopamine uptake in rat nucleus accumbens, but not in striatum. Brain Res 531:338-341

Izenwasser S, Cox BM (1992): Inhibition of dopamine uptake by cocaine and nicotine: Tolerance to chronic treatments. Brain Res 573:119-125

Johanson ChE, Fischman MW (1989): The pharmacology of cocaine related to its abuse. Pharmacol Rev 41:3-52

Kessler RM, Whetsell WO, Ansari MS, Votaw JR, de Paulis T, Clanton JA, Schmidt DE, Mason NS, Manning RG (1993). Identification of extrastriatal dopamine $D_{2}$ receptors in post mortem human brain with [125I]epidepride. Brain Res 609:237-243

Koob GF, Bloom FE (1988): Cellular and molecular mechanism of drug dependence. Science 242:715-723

Kula NS, Baldessarini RJ (1991): Lack of increase in dopamine transporter binding or function in rat brain tissue after treatment with blockers of neuronal uptake of dopamine. Neuropharmacology 30:89-92

Kumor K, Sherer M, Jaffe J (1987): Haloperidol-induced dystonia in cocaine addicts. Lancet 2:1341-1342

Little KY, Kirkman JA, Carrol FI, Clark TB, Duncan GE (1993): Cocaine use increases [ $\left.{ }^{3} \mathrm{H}\right]$ WIN 35428 binding sites in human striatum. Brain Res 62:17-25

Logan J, Fowler JS, Volkow ND, Wolf AP, Dewey SL, Schlyer DJ, MacGregor RR, Hitzemann R, Bendirem B, Gatley SJ, Christman DR (1990): Graphical analysis of reversible radioligand binding from time activity measurements applied to [N-11 C-methyl]-(-)cocaine PET studies in human subjects. J Cereb Blood Flow Metab 10:740747

Logan J, Volkow ND, Fowler JS, Wang G-J, Dewey SL, MacGregor R, Schlyer D, Gatley S], Pappas N, King P, Hitzemman R, Vitkun S (1994): Effects of blood flow on $\left[{ }^{11} \mathrm{C}\right]$ raclopride binding in the brain: model simulations and kinetic analysis of PET data. J Cereb Blood Flow Metab 14:995-1010

London ED, Cascella NG, Wong DF, Phillips RL, Dannals RF, Links JM, Herning R, Grayson R, Jaffe JH (1990): Cocaineinduced reduction of glucose utilization in human brain. A study using positron emission tomography and [fluorine-18]-fluorodeoxyglucose. Arch Gen Psychiatry 47:567574

Madras BK, Kaufman MJ (1994): Cocaine accumulates in dopamine-rich regions of primate brain after IV administration: Comparison with mazindol distribution. Synapse 18:261-275

Malison RT, Wallace EA, Best S, Gandelman M, Zoghbi SS, Zea Ponce Y, Baldwin RM, Charney DS, Hoffer PB, Kosten TR, Innis RB (1994): SPECT imaging of dopamine transporters in cocaine dependent and healthy control subjects with [123] 3 CIT. 24th Annual Meeting, Society for Neurosciences Abstracts 20:1625

Matsui T, Hirano A (1978): An Atlas of the Human Brain for Computerized Tomography. Stuttgart, Gustav Fisher Verlag

Missale C, Castelletti L, Govoni S, Spano PF, Trabucchi M, Hanbauer I (1985): Dopamine uptake is differently regulated in rat striatum and nucleus accumbens. J Neurochem 45:51-56
Mule SJ, Casella GA, Misra AL (1976): Intracellular disposition of $[3 \mathrm{H}]$-cocaine, $[3 \mathrm{H}]$-norcocaine, $[3 \mathrm{H}]$-benzoylecgonine, and $[3 \mathrm{H}]$-benzoilnorecgonine in the brain of rats. Life Sci 19:1585-1596

Ng JP, Hubert GW, Justice JB Jr (1991): Increased stimulated release and uptake of dopamine in nucleus accumbens after repeated cocaine administration as measured by in vivo voltammetry. J Neurochem 56:1485-1492

Pan HT, Meancherry S, Justice RB Jr (1991): Differences in the pharmacokinetics of cocaine in naive and cocaine-experienced rats. J Neurochem 1299-1306

Parsons LH, Schad CA, Justice JB Jr (1993): Co-administration of the $\mathrm{D}_{2}$ Antagonist Pimozide Inhibits Up-Regulation of Dopamine Release and Uptake Induced by Repeated Cocaine. Journal of Neurochemistry, New York, Raven, pp 376-379

Parsons LH, Smith AD, Justice JB Jr (1991): Based extracellular dopamine is decreased in the rat nucleus accumbens during abstinence from chronic cocaine. Synapse 9:60-65

Peris J, Boyson SJ, Cass WA, Curella P, Dwoskin LP, Larson G, Lin LH, Yasuda RP, Zahniser NR (1990): Persistence of neurochemical changes in dopamine systems after repeated cocaine administration. J Pharmacol Exp Ther 254:38-44

Pettit HO, Pan HT, Parson LH, Justice JB Jr (1990): Extracellular concentrations of cocaine and dopamine are enhanced during chronic cocaine administration. J Neurochem 55:798-804

Pilotte NS, Sharpe LG, Kuhar MJ (1994): Withdrawal of repeated intravenous infusions of cocaine persistently reduces binding to dopamine transporters in nucleus accumbens of lewis rats. JPET 269:963-969

Reith MEA, Benuck M, Lajtha A (1987): Cocaine disposition in the brain after continuous or intermittent treatment and locomotor stimulation in mice. J Pharmacol Exp Ther 243:281-287

Ritz MC, Lamb RJ, Goldber SR, Kuhar MJ (1987): Cocaine receptors on dopamine transporters are related to self administration of cocaine. Science 237:1219-1223

Salmon E, Brooks DJ, Leenders KI, Turton DR, Hume SP, Cremer JE, Jones T, Frackowiak RSJ (1990): A two-compartment description and kinetic procedure for measuring regional cerebral $\left[{ }^{11} \mathrm{C}\right]$ nonifensine uptake using positron emission tomography. J Cereb Blood Flow Metab 10:307316

Sharpe LG, Pilotte NS, Mitchell WM, DeSouza EB (1991): Withdrawal of repeated cocaine decreases autoradiographic ${ }^{3} \mathrm{H}$-mazindol labeling of dopamine transporter in rat nucleus accumbens. Eur J Pharmacol 203:141-144

Smith M, Wolf AP, Brodie JF, Arnett CD, Barouche F Schiue C-Y, Fowler JS, Russell JAG, MacGregor RR, Wolkin A, Angrist B, Rotrosen J, Peselow E (1988): Serial 18-F N Methylspiroperidol PET studies to measure changes in antipsychotic drugs $D_{2}$ receptor occupancy in schizophrenic patients. Biol Psychiatry 23:653-663

Stoof JC, Kebabian JW (1982): Independent in vitro regulation by $D_{2}$ receptor of dopamine stimulated efflux of cAMP and potassium stimulated release of acetylcholine from rat neostriatum. Brain Res 250:263-270

Volkow ND, Fowler JS, Wang G-J, Logan J, Schlyer D, Mac Gregor R, Hitzemann R, Wolf AP (1994): Decreased 
dopamine transporters with age in healthy human subjects. Ann Neurol 36:237-239

Volkow ND, Fowler JS, Wolf AP, Schlyer D, Schiue C-Y, Alpert R, Dewey SL, Logan J, Bendriem B, Christman D, Hitzemann R, Henn F (1990): Effects of chronic cocaine abuse on postsynaptic dopamine receptors. Am J Psychiatry 147:719-724

Volkow ND, Mullani N, Gould KL, Adler S, Krajewski K (1988): Cerebral blood flow in chronic cocaine users. Br J Psych 151:641-648

Volkow ND, Fowler JS, Wang G-J, Hitzemann R, Logan J, Schlyer D, Dewey S, Wolf AP (1993): Dopaminergic dysregulation of frontal metabolism may contribute to cocaine addiction. Synapse 14:169-177

Volkow ND, Fowler JS, Logan J, Gatley JS, Dewey SL, MacGregor RR, Schlyer DJ, Pappas N, King P, Wolf AP (1995): Comparison of $\left.{ }^{11} \mathrm{C}\right]$ cocaine binding at subpharmacologic and pharmacologic doses in baboon brain: A PET study. J Nucl Med 36:1289-1297

Volkow ND, Fowler JS, Wolf AP, Hitzemann R, Dewey S, Bendriem B, Alpert R, Hoff A (1991): Changes in brain glucose metabolism in cocaine dependence and withdrawal. Am J Psych 148:621-626

Volkow ND, Hitzemann R, Wang GJ, Fowler JS, Wolf AP, Dewey SL (1992): Long-term frontal brain metabolic changes in cocaine abusers. Synapse 11:184-190
Wang G-J, Volkow ND, Fowler JS, Wolf AP, MacGregor R, Shea CE, Shyler D, Hitzemann R (1993): Comparison of two PET radioligands for imaging extrastriatal dopamine receptors in human brain. Synapse 15:246-249

Wilson JM, Carrol M, Niznik HB, Kish SJ (1992): Differential regulation of the cocaine acceptor and dopamine uptake sites following cocaine self-administration. Soc Neurosci Abstr 18:1078

Wise RA (1990): Neural mechanisms of the reinforcing actions of cocaine. In Volkow ND, Swann A (eds), Cocaine in the Brain. New Brunswick, Rutgers University Press, pp 42-57

Woolverton WL, Johnson KM (1992): Neurobiology of cocaine abuse. Trends Pharmacol Sci 31:193-200

Wyatt RJ, Karoum F, Suddath R, Fawcett R (1988): Persistently decreased brain dopamine levels and cocaine. JAMA 27:2996

Xia Y, Goebel DJ, Kapatos G, Bannon MJ (1992): Quantitation of rat dopamine transporter mRNA. Effects of cocaine treatment an1d withdrawal. J Neurochem 59:1179-1182

Yi SJ, Johnson KM (1990): Effects of acute and chronic administration of cocaine on striatal dopamine uptake compartmentalization and release of $\left[{ }^{3} \mathrm{H}\right]$ dopamine. Neuropharmacology 29:475-486 